\title{
Corporate Governance And Fraud
}

Rae Weston, (E-mail: Rae.weston@mgsm.edu.au),Macquarie Graduate School of Management, Australia

\begin{abstract}
The main bank fraud cases of the past decade are examined to identify warning signs that could and should have been recognised. Brown (2001 and 2004) has rightly highlighted doubling as a key feature of the Leeson and National Australia Bank derivatives losses. This paper takes a wider view of this and other similar events-the Allied Irish fraud, the Sumitomo copper case, the Daiwa Bank losses and the National Australia Bank case - and examines the other warning signs that could and should have been recognised. If these can be seen as easier to identify while the fraud is in progress than the doubling of transactions, then these may be used to structure an early warning system of some potency.
\end{abstract}

\section{BROWN}

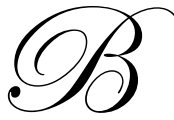

rown (2001 and 2004) has rightly highlighted doubling as a key feature of the Leeson and National Australia Bank derivatives losses. This paper takes a wider view of this and other similar events-the Allied Irish fraud, the Sumitomo copper case, the Daiwa Bank losses and the National Australia Bank case - and examines the other warning signs that could and should have been recognised. If these can be seen as easier to identify while the fraud is in progress than the doubling of transactions, then these may be used to structure an early warning system of some potency. This paper is structured as follows: in the next section we summarise the Sumitomo Copper, Daiwa Bank and Leeson cases and identify at the end of each what warnings signs could have been seen. We then consider these signs and note the common factors. In sections three and four we consider in turn and at more length the Allied Irish and National Australia Bank cases and note at the end of these two sections the warning signs. In section five we examine the catalogue of warning signs and ask whether they should or would have been easier to identify than the "doubling" concerns. In the final section we summarise our findings and suggest how these may be used to structure an early warning system.

\section{SUMITOMO COPPER}

In June 1996 the report of an investigation by the UK Securities and Investment Board (SIB) revealed that losses of $\$ 1.8$ bn had been accumulated from unauthorized trading at Sumitomo Corporation, a leading copper dealer. The company attributed blame for the losses to Yasuo Hamanaka, a former head of copper trading, but nevertheless emphasized that it would stand behind its copper market obligations, and recognized that the losses could rise if the copper price fell.

The American Metal Market reported (June 17, 1996) that: "Executives said they learned of the losses June 5 when Hamanaka allegedly admitted to unauthorized trading." This admission followed the discovery in late April and early May of unaccounted-for bank transactions that led to Hamanaka's removal from trading and further investigations led to the confession, executives said. A second unidentified trader who left the company eight years ago was the only other mentioned.

The market Hamanaka had been trading in was the London Metal Exchange forward market for copper. In this market, positions taken are normally for three months, but there is the ability to roll positions forward, thereby deferring the settlement and crystallization of profit or loss date. Sumitomo was the largest participant in the physical market for copper, handling twice the volume of its nearest competitor. Hamanaka was known in the copper markets as "Mr. Five Percent" because Sumitomo's copper trading team traded approximately 500,000 metric tons of copper a year, which was $5 \%$ of the total world demand for copper. Hamanaka was quoted in the company's Annual Report in the early 1990s accounting for the company's significance in the market as "attributable to expertise in risk management." 


\section{What Warning Signs Were There?}

Sumitomo had had its attention drawn to possible irregularities in its copper market dealings before: first in 1991 by the LME when David Threlkeld, one of its metal brokers reported being asked by Hamanaka for an invoice for non-existent trades; secondly in 1994 when an inquiry by the UK Securities and Futures Authority (UK) into the relationship between Winchester and a Chilean trader acting for Codelco led the authority to notify Sumitomo that Winchester had made most of its money acting as a broker for Sumitomo; and, third, in early 1996 when the SIB and the US CFTC began to investigate the copper market it was clear that the company's activities in the market would be of interest to them. Had the second of these warning signs been investigated this might have led to earlier discovery of the irregularities.

\section{Leeson And Baings Bank}

Nick Leeson was appointed general manager, head trader and head of back office operations for Barings Securities (Singapore) Ltd and began to take unauthorised positions in Nikkei 225 futures, Japanese government bond (JGB) futures and options on the Nikkei. When he was unsuccessful, he increased the size of his positions only to lose more. By the end of 1992 the account in which he hid these trades, BSS error account number 88888 had a loss of 2 million GBP, which by the end of 1993 had reached 23m GBP and by the end of 1994 208m GBP.

Because his trades were losing money he was required to make margin calls to SIMEX and did so by making a series of account falsifications and misrepresentations to secure these funds.

Leeson used the cross trade facility to move his losses into officially recorded profits that generated him bonuses. A cross trade is a trade executed on the floor of an exchange by a member who has matching buy and sell orders from two different customer accounts for the same contract at the same price. Leeson did cross transactions between his account 88888 and the accounts of Barings Securirtes Japan-Nikkei and JGB arbitrage, Barings LondonJGB arbitrage and Barings London-Euroyen arbitrage. After the trades were executed Leeson had his settlement staff move the contracts into several different trades and change the trade prices so that profits were credited to the Barings accounts and the losses to account 88888 . This in effect made Barings the counterparty to its own trades and moved its position from arbitrage to speculation.

It appears that Leeson's covering of his tracks was assisted by the November 1993 merger of BSl with the banking business, Barings Brothers and Company in the expectation of forming a Barings Investment Bank. The merger was complicated by the very different cultures of the two businesses and while Barings was in the throes of creating a risk management function, there was no-one within the organisation responsible for the supervision of Leeson's several conflicting roles.

On January 131995 when the Nikkei reached 19331, Leeson was long 3024 Nikkei futures contracts. Three days after the January 17 Kobe earthquake had caused the Nikkei to drop below 188840, Leeson doubled his number of contracts to 7135. By the time the Nikkei reached 18000 on February 23, his exposure was more than 55,339 unhedged contracts and he had significant losses on the JGB futures contract as well. On February 231995 Leeson fled from Singapore and on February 24 Barings found that it was 827 GBP in debt from the trades, more than double its capital.

While the Bank of England and a consortium led by Barclays Bank attempted a bailout, when it was realised that there were almost certainly further as yet undiscovered losses, the efforts failed. The losses rose by one third on February 27 and Barings was bankrupt.

\section{What Warning Signs Were There?}

Barings ignored a notice sent by London's Securities and Futures Authority only days after Leeson arrived in Singapore about two outstanding debts he had neglected to mention on his application for a trading license in London which was refused for that reason. In March 1992 a Barings' director wrote a memo in which he warned that the 
business was "in danger of setting up a structure which will subsequently prove disastrous" (Dalglish and Wallace (1995)). In 1993 Peter Baring, Chairman of Barings said the Brian Quinn, a director of the Bank of England that "The recovery in profitability has been amazing following the reorganisation, leaving Barings to conclude that it is not actually terribly difficult to make money in the securities market." In August 1994 according to an investigation by Simex an internal audit of the Singapore office warned that Leeson had "excessive" power. On January 27, 1995 in a letter sent to James Bax head of BSS in Singapore, SIMEX expressed concerns about the ability of Barings to fund its marginal calls, which was not surprising as by this time Leeson's trades accounted for more than $40 \%$ of the entire Barings business profits. Bax referred the letter to London and SIMEX received reassurance that opposite positions were being held in Japan. Unfortunately, Simex officials did not follow up with the Osaka Exchange to verify the existence of those positions. In a January 1995 internal e-mail, Brenda Granger, Head of Futures and Options Settlements in London said: "Awaiting breakdown from my buddy Nick ... (once they creatively allocate the numbers)".

\section{Daiwa Bank}

Toshihide Iguchi joined Daiwa Bank in 1976 and in 1976 was given responsibility for both trading and accounting in the trading of US government bonds and in 1986 he became head of Daiwa's government bond trading operation in New York. In 1983 he made a trading loss of $\$ 200,000$ on US Treasury bonds and covered this up while attempting to trade so as to win the money back. He continued to make losses but hid records and forged trading documents to make it appear that the bank continued to own securities he had actually sold.

The Federal Reserve had warned Daiwa at least twice that there was a potential problem with Iguchi both trading and accounting.

On September 18, 1995 Daiwa Bank met with a representative of the Federal Reserve Bank and reported that its New York branch had incurred losses of \$US1.1 billion from trading activities undertaken by Toshihide Iguchi over a period of 11 years. These losses had not been reflected in the books and records of the bank nor in its financial statements. Their existence had been concealed, as Iguchi had suggested, through liquidations of securities held in the bank's custody accounts and falsification of its custody records.

Iguchi in a later interview (Time, 1997) said "I traded the same bonds for 12 years .It was pretty simple for management to understand. I had several managers over me who should have understood. But the New York branch depended on me so heavily for profits-we were producing more than half their profits-they wanted to keep their eyes closed and they didn't want to know anything."

On September 18, 1995 Daiwa Bank met with a representative of the Federal Reserve Bank and reported that its New York branch had incurred losses of \$US1.1 billion from trading activities undertaken by Toshihide Iguchi over a period of 11 years. These losses had not been reflected in the books and records of the bank nor in its financial statements. Their existence had been concealed, as Iguchi had suggested, through liquidations of securities held in the bank's custody accounts and falsification of its custody records.

\section{Were There Signs?}

In both 1993 and 1994 the US regulators had warned Daiwa about its poor internal controls, however it appears that Daiwa misled them by claiming that Iguchi no longer performed both front and back office functions.

Daiwa said that the losses had been concealed from US banking regulators for almost two months and that its officials had directed Iguchi to continue transactions during the two month period so as to avoid disclosure of the losses. Some Japanese Ministry of Finance officials had been informed in early August of Daiwa's losses but did not either instruct Daiwa to inform the US authorities or do so themselves. 
In all three cases signs of irregular trading were drawn to the attention of the entities responsible and concerns were also expressed by relevant market and/or regulatory authorities well in advance of the "discovery" of the frauds.

\section{ALLIED IRISH BANK}

In 1993 John Rusnak moved from Chemical Bank in New York to Maryland Bancorp as a foreign exchange trader claiming to be" an experienced foreign exchange options trader with an arbitrage style of trading". While he claimed to have this experience it seems that his style was effectively simply directional trading. In 1997 the Allied Irish Bank (AIB) acquired Dauphin Deposit Corporation and in 1999 Allfirst was created by the merger of First Maryland Bancorp and Dauphin Deposit Corporation .It was the American arm of AIB.

In 1997 Rusnak made some unsuccessful currency forward trades on the Japanese yen, without taking out options to protect his positions. His forward positions required the yen to strengthen against the dollar but instead it fell. Without protective options these positions made serious losses. In order to cover his tracks Rusnak created fictitious option positions by entering two non-existent trades into the bank's trading system. While the two option positions had the same currency and strike price, one would involve receiving a premium and would expire on the same day it was supposedly written, while the other one would not expire for a month or so..

Rusnak continued this scheme for concealing these and further losses into 1998, but in September of that year he was able to persuade one of the back office staff that confirmation of the bogus transactions was not required because no cash was transferred. What appeared in the bank's books was an asset- an unexpired deep-in-the-moneyoption- for which it had allegedly paid a large premium. The "asset" would be rolled over into new bonus options on the expiry date of the original ones. profits.

In his real trading Rusnak was continuously inept except for a minor period in late 1999 when he made a few

In 1999 Rusnak moved to another even better means of concealment by using prime brokerage accounts, which enabled him to make trades in prime brokers' names with monthly settlements and no collateral requirements. Rusnak simply put bogus deals into the system (known as DEVON) used to record prime brokerage account trades and reversed them prior to the monthly settlement. By this process Rusnak was able to conceal increasing trading activity and associated losses.

In 2000 Allfirst's treasurer decided that trading income should carry a charge for the cost of balance-sheet usage from January 2001.The introduction of this procedure drew attention to Rusnak's level of activity as his earnings were insufficient to justify his use of the balance sheet and he was ordered to reduce his use of the balance sheet.

This forced him to find a way to outsource his balance sheet funding. What he did was to sell year-long deep in-the-money options for which large premiums were received. Five sold options raised $\$ 300$ million which could be used to help fund the monthly settlement of his foreign exchange transactions... The options Rusnak sold were recorded on Allfirst's books as liabilities and in order to get these off the books he again created bogus transactions which repurchased the original options. As a result Allfirst had substantial but unrecorded liabilities...

Allfirst's treasury funds policy allocated Rusnak $\$ 1.55$ million of the total $\$ 2.5$ million foreign exchange trading value at risk limit. Because his bogus options were taken to be hedges of his real positions, the value at risk amount required was reduced. In addition Rusnak used bogus figures for his holdover transactions which had the effect of reducing his bogus option positions and again reducing the value at risk requirement.

In December 2001 the direct supervisor of the back office employee whose job was to confirm foreign exchange options noticed on the employee's desk two trade tickets that did not have the required confirmations attached. On being asked if the trades were valid where were the confirmations, the employee confirmed they were 
valid transactions but that as they offset each other and were with Asian counterparties they did not require confirmations... The employee claimed that the supervisor told him merely to look into the possibility of confirming the Asian trades, while the supervisor said that he had directed the employee to confirm all trades in future.

Also in December 2001 Allfirst's treasurer ordered that the balance sheet position for currency trading be reduced to under $\$ 150$ million and in January this appeared to have been done suddenly in mid-January it rose again to over $\$ 200$ million and in noticing that the treasurer also noted that December trading had been $\$ 25$ billion. Concerned at Rusnak's role in these figures the treasurer proposed closing down Rusnak's trading and on January 28 this was announced at a staff meeting. On January 30 the back office supervisor checked to see if Rusnak was still trading and found with the handful of trades deal tickets without confirmations. When an employee was instructed to call the alleged Asian counterparties to confirm these trades it was found that they either did not have those currency options on their books or did not trade currency options at all. In the subsequent attempts to follow this up Rusnak's supervisor warned that job cuts in the back office would be likely if Rusnak left the bank and took his profitable trading with him.

Faced with having to produce documents that were non-existent, Rusnak vanished and after the matter was reported to the treasurer, an intensive investigation revealed the scale of the fraud.

\section{Were There Signs?}

In 1997 a manager of AIB asset/liability management area who reported to the group treasurer noted that Rusnak was accountable for $95 \%$ of the bank's foreign exchange risk with about 100 transactions per day, about $80 \%$ speculative and $20 \%$ corporate-driven.

Prior to 1998 Allfirst was supervised by the (US) Office of the Comptroller of the Currency had raised concerns about risk management in the foreign exchange trading area including dealers exceeding limits; inadequate information provided to ALCO and a lack of reviews of foreign exchange trades for off-market prices.

There had been consistent reports, certainly from 1999 onwards of irregular practices used by Rusnak in his transactions. These had included the use of what were termed "controlled settlements"-the withholding of payment on trades so as to eliminate settlement risk; and problems with the confirmation of transactions.

In March 2000 AIB's group treasurer received an inquiry from Citibank about a gross monthly prime account settlement of over $\$ 1$ billion scheduled for the beginning of April. There was no follow-up on why the positions were so large.

According to the Ludwig Report (2002 at p.23) in late May 2001, a market source suggested to AIB that Allfirst "was engaging in very heavy foreign exchange trading" but received "a forceful and categorical denial of any problem." In September or October 2001 the SEC sent a comment letter on Allfirst's financial statements including questions concerning the cash flow related to foreign exchange activity.

\section{NATIONAL AUSTRALIA BANK}

The currency options team responsible for the losses began trading for NAB in 1998 with three dealers, increasing to four in 2000. While the team's original mandate was to grow both customer business and proprietary trading, the appointment of the current executive general manager for Corporate and Institutional Banking, Mr Scholes shifted the official focus of the business to sales to corporate and institutional customers with the intention that in the financial year to 30 September 2004 , trading income would only be $30 \%$ of its total foreign exchange income.

In September 2001, but perhaps earlier as the gap exploited had been uncovered by accident in 2000, the traders began to shift profits and losses from one day to another so as to conceal losses. They described this practice as 
"smoothing". They may well have used incorrect revaluation rates to value the currency options portfolio from July 1998 because of poor control of what was intended to be an independent revaluation process.

In 2001 and 2002, the value of the currency options book was overstated. This was accomplished by using a gap in the Horizon processing timeline. This worked by the front office entering false trade details after the back office had informed them that Horizon end-of-day processing would be starting. In 2003 a second method of falsifying transactions was introduced by the traders, also exploiting the one-hour window. This method created and then removed false one-sided internal spot foreign exchange transactions. typically by recording a profit in the currency options book which failed to have a matching loss elsewhere within NAB PricewaterhouseCoopers(PWC) identified 467 false transactions in 2003.

From 24 October 2003 when the traders realised that the back office was not checking internal option transactions, a third method was used, which was simply to now use options with longer than daily maturities, although one-sided transactions would have to be surrendered prior to maturity. PWC identified 78 of these false internal options in 2003

In the December quarter of 2003 NAB's currency options desk took an aggressive series of proprietary trades so as to position its currency options positions in the expectation that the falls in the \$US of mid-year would reverse and that volatility would stabilise., especially after the G-7 meeting on 22 September. The desk sold "butterfly spreads" which were long at-the-money volatility and short out-of-the-money volatility.

In fact there was a significant and continuous weakening of the \$US following the G-7 meeting but the dealers persisted in their positions and tried to mask the growing actual losses by entering fictitious trades. They were already masking carried forward loss positions from the September 2003 financial year.

By early 2004 as the traders widened their proprietary deals to the $\$$ US/JPY, GBP/\$US and $\$ N Z / \$ U S$, further and increasing losses were made. In January 2004 the US dollar fell against the US dollar and losses of \$A30 million and \$A39 million were incurred. On January $13 \mathrm{Nab}$ announced a loss of \$A180 million from unauthorised dealing within its currency options business, a loss subsequently marginally adjusted to \$A185 million on January 19 and restated as \$A360 million on January 27.

\section{Warning Signs}

The currency options area had first come to attention as early as May 1999 when Internal Audit rated currency options as "unsatisfactory" with five issues defined as three-star which signified "Serious matters for the attention of the Managing Director and reportable to the Board Audit Committee" and which in Internal Audit's view "essentially arise from an inadequate control framework surrounding the unique characteristics of dealing in currency options". In particular they drew attention to the inability to reconcile profit and loss between the front and the back offices; no volatility smile included in revaluations as required and no independent monitoring of risk concentrations. These were the gaps that the dealing team were able to exploit.

It was suggested that the FX Options Horizon, a custom-built system, would mitigate several of the weaknesses raised but would not deal with either the volatility smile issue nor the broader security strategy issues. No review of the success or otherwise of Horizon in meeting any of the concerns seems to have been done.

In its December 2001 report Internal Audit drew attention to two three-star issues with respect to currency option trading: first, continuous limit breaches for 61 out of 61 days which, while approved by the Global Head of Foreign Exchange, were not made with any documentation to explain the breaches or to suggested how the breaches might be rectified.; and, second that the VaR numbers being produced were incorrect because no volatility smile was used. Further, the report noted that major revaluation rates were being sourced by the front office from only one broker. 
Nevertheless, these matters were not reported to the Principal Board Audit Committee (PBAC).

The external auditor, KPMG, noted four issues with respect to NAB's options area in its January 2002 report, although they were ranked as minor. They were that the valuations at mid-market might overstate fair values of derivatives; as no volatility smile was used for some currency options this might lead to mispricing; that insufficient effort was devoted to the crucial task of identifying and assessing portfolio risks; and that the results of stress testing and scenario analysis was neither discussed with senior management nor presented to the Board.

As a consequence of a review of market risk performed from 26 to 30 August 2002 the Australian Prudential Regulatory Authority (APRA) reported "some issues noted below that we expect the Bank to address promptly owing to potential for those issues to give rise to significant problems in the future". APRA's report went to the EGM Group Risk Management, and the Chairman in January 2003. The issues noted with respect to currency options were lax approach to limit management; a culture of non-adherence to risk management policies; capture of valuation rates by the dealers rather than independent validation; a lack of formal model validation or back-testing for the approved VaR model and inadequate stress-testing. A response to APRA from senior management was not tabled at the Board.

\section{CONCLUSION}

In all five cases analysed above there were signs of "irregular trading" that went either not investigated or under-investigated. Even more importantly in every case a regulatory or supervisory authority had drawn attention to the potential problem area but was answered without careful investigation of the issues raised. In the Sumitomo case the London Metals Exchange drew management's attention to an invoice for non-existent trades; SIMEX clearly signalled the potential liabilities that Leeson was building up to Barings; the US regulators warned Daiwa Bank about the risk of the coincidence of trading and accounting functions being taken by the same person; both the market and regulators drew Allied Irish's attention to the risks in their foreign exchange trading area; and the Australian Prudential Regulatory Authority reported to the National Australia Bank some issues that might give rise to significant problems in the future.

How can we put these findings into an early warning system that would work ? This is especially an issue in the light of the failure of any learning process from earlier failures. National Australia's bank board for example was given an extensive briefing on the Allied Irish case and dismissed the possibility of it happened to their bank at the same time as the same methods of concealment used by Rusnak were concealing currency option frauds within their own organisation.

It is difficult to see the doubling of the size of transactions as a real early warning indicator because the volumes in these markets tend to be volatile and a reasonable explanation could simply be that the market volume had increased.

A step in the process to make the concerns of authorities to be more transparent to the shareholders might be to require these to be listed in the annual report together with the entity's response. This would eliminate the claim to complete ignorance of the circumstances often alleged by board members in loss situations. For entities trading reasonably their responses in the annual reports would allay shareholder concerns; and for those not trading within reasonable limits perhaps this may serve as an early warning to the board and to senior management that it may have some concealed problems.

It would be easy to point to the lack of ability of those in direct supervision of the traders concerned in all of the above cases but the responsibility for this should clearly rest much further up the organisational hierarchy. Concerns expressed by market and regulatory authorities if much more clearly identified to shareholders would create the necessary incentive to see that boards and senior management much more clearly understand the nature of the risks that many specialised area have and a real incentive to ensure that much greater regard is taken for the concerns raised. 


\section{REFERENCES}

1. Abegglen, James C. (2001) Japan's industries and companies: economic dynamism and social continuity in Freedman, Craig (ed) Economic Reform in Japan, Edward Elgar.

2. $\quad$ APRA (2004) Report into Irregular Currency Options Trading at the National, APRA, 24 March.

3. $\quad$ AsiaWeek (1995) Japan's \$1 billion scam AsiaWeek October 27.

4. Bank of England (1995) Report of the Board of Banking Supervision Inquiry into the Cause of the Collapse of Barings.

5. Brown, Stephen and Onno W. Steenbeck (2001) Doubling: Nick Leeson's trading strategy Pacific Basin Finance Journal, 9.

6. Brown, Stephen (2004) Doubling the risk of damnation Australian Financial Review January 21.

7. Charkham, J. (1995) Keeping Good Company OUP, Oxford.

8. Dalglish, Brenda and Bruce Wallace (1995) Barings Bank collapses MacLean's, March 13.

9. Futatsugi, Y. (1990) What Cross Shareholdings Mean for Corporate Management Economic Eye.

10. Gilson, R. and M. Roe (1993) Understanding the Japanese keiretsu: Overlaps between Corporate Governance and Industrial Organization Yale Law Journal 102.

11. Goldstein, Jon (2002) Learning from Allfirst's mistake Baltimore Sun 13 February.

12. Hamada, Koichi (2001) Can the Japanese change? Organizational, psychological and evolutionary perspectives in Freedman, Craig (ed) Economic Reform in Japan, Edward Elgar.

13. Jaffa, Sam (1998) Great Financial Scandals, Robson Books.

14. Jarecki, Henry (1976) Silver Threads Among the Gold Euromoney.

15. Kane, E.J. and K. DeTrask (1999) Breakdown of accounting controls at Barings and Daiwa: Benefits of using opportunity cost measures for trading activity Pacific Basin Finance Journal 7 (3-4).

16. Leith, William (2002) How to lose a billion The Guardian 26 October.

17. Lerner, Dan (2002) Ludwig heads probe into AIB scandal The Scotsman 11 February.

18. McDougall, Dan (2002) Allied Irish mounts investigation into failed security procedures The Scotsman 8 February.

19. McDougall, Dan (2002) The 750 million dollar man The Scotsman 7 February.

20. Miles, Lilian (1998) Corporate Governance in Japan: An Overview and Evaluation Business Law Review March.

21. PricewaterhouseCoopers (2004) Investigation into the foreign exchange losses at the National Australia Bank, March.

22. Roddy, Michael (2002) Irish Bank wrestles with $\$ 750$ million fraud impact Tallahassee.com 7 February.

23. Time (1997) Interview I didn’t set out to rob a bank Time vol 149, No 6 February 10.

24. Tran, Mark (2002) Allied Irish fraud began in 1997 Fuardian Unlimited 20 February.

25. Wachtell, Lipton, Rosen, Katz, and Promontory Financial Group (The Ludwig Report) (2002) Report to the Boards of Allied Irish Banks p.l.c., Allfirst Financial Inc and Allfirst Bank concerning Currency Trading Losses.

26. Weston, Rae (2003) The Sumitomo Copper fraud: Were there signs? Academy of Legal, Ethical and Regulatory Issues Proceedings, April.

27. Weston, Rae (2005) The NAB foreign currency option losses in the context of a disaster myopia model Journal of Financial Services Marketing Vol 9 Special Issue. 